\title{
Zinc oxide nanoparticles selectively induce apoptosis in human cancer cells through reactive oxygen species
}

This article was published in the following Dove Press journal:

International Journal of Nanomedicine

17 February 2012

Number of times this article has been viewed

\author{
Mohd Javed Akhtar ${ }^{1,2}$ \\ Maqusood Ahamed ${ }^{3}$ \\ Sudhir Kumar' \\ MA Majeed Khan ${ }^{3}$ \\ Javed Ahmad ${ }^{4}$ \\ Salman A Alrokayan ${ }^{3}$ \\ 'Department of Zoology, University \\ of Lucknow, Lucknow, India; ${ }^{2}$ Fibre \\ Toxicology Division, CSIR-Indian \\ Institute of Toxicology Research, \\ Lucknow, India; ${ }^{3}$ King Abdullah \\ Institute for Nanotechnology, King \\ Saud University, Riyadh, Saudi Arabia; \\ ${ }^{4}$ Department of Zoology, College of \\ Science, King Saud University, Riyadh, \\ Saudi Arabia
}

Background: Zinc oxide nanoparticles (ZnO NPs) have received much attention for their implications in cancer therapy. It has been reported that ZnO NPs induce selective killing of cancer cells. However, the underlying molecular mechanisms behind the anticancer response of $\mathrm{ZnO}$ NPs remain unclear.

Methods and results: We investigated the cytotoxicity of $\mathrm{ZnO}$ NPs against three types of cancer cells (human hepatocellular carcinoma HepG2, human lung adenocarcinoma A549, and human bronchial epithelial BEAS-2B) and two primary rat cells (astrocytes and hepatocytes). Results showed that $\mathrm{ZnO}$ NPs exert distinct effects on mammalian cell viability via killing of all three types of cancer cells while posing no impact on normal rat astrocytes and hepatocytes. The toxicity mechanisms of ZnO NPs were further investigated using human liver cancer HepG2 cells. Both the mRNA and protein levels of tumor suppressor gene p53 and apoptotic gene bax were upregulated while the antiapoptotic gene bcl-2 was downregulated in ZnO NPtreated HepG2 cells. ZnO NPs were also found to induce activity of caspase-3 enzyme, DNA fragmentation, reactive oxygen species generation, and oxidative stress in HepG2 cells.

Conclusion: Overall, our data demonstrated that ZnO NPs selectively induce apoptosis in cancer cells, which is likely to be mediated by reactive oxygen species via p53 pathway, through which most of the anticancer drugs trigger apoptosis. This study provides preliminary guidance for the development of liver cancer therapy using $\mathrm{ZnO}$ NPs.

Keywords: $\mathrm{ZnO}$ nanoparticles, cancer therapy, p53, apoptosis, ROS

\section{Introduction}

Nanotechnology allows the manipulation of materials at nanoscale level (1-100 nm), which enables precision engineering to control nanoparticles' (NPs') physicochemical properties, as well as their interactions with biological systems. ${ }^{1,2}$ Inorganic NPs, including metal oxides, are promising materials for applications in medicine, such as cell imaging, biosensing, drug/gene delivery, and cancer therapy. ${ }^{3-5}$ Zinc oxide ( $\left.\mathrm{ZnO}\right)$ NPs belonging to a group of metal oxides are characterized by their photocatalytic and photo-oxidizing ability against chemical and biological species.

In recent times, $\mathrm{ZnO}$ NPs have received much attention for their implications in cancer therapy. ${ }^{6}$ Studies have shown that ZnO NPs induce cytotoxicity in a cellspecific and proliferation-dependent manner, with rapidly dividing cancer cells being the most susceptible, and quiescent cells being the least sensitive. ${ }^{7-9}$ Clearly, the type of cell in question is important when considering the cytotoxicity of ZnO NPs toward mammalian cells. To date, however, the anticancer activity of ZnO NPs, especially 
the underlying mechanisms of apoptosis in cancer cells due to $\mathrm{ZnO}$ NP treatment, is largely lacking.

Apoptosis is a key process in cancer development and progression. The ability of cancer cells to avoid apoptosis and continue to propagate is one of the fundamental hallmarks of cancer and is a major target of cancer treatment. Apoptosis is controlled by a large number of genes acting as death switches. The tumor suppressor gene p53 is regarded as the master guardian of the cell and is able to activate cell-cycle checkpoints, DNA repair, and apoptosis to maintain genomic stability. ${ }^{10}$ In the presence of DNA damage, p53 protein triggers cell-cycle arrest to provide time for the damage to be repaired or for selfmediated apoptosis. ${ }^{11,12}$ The bax/bcl-2 protein ratio determines the life or death of cells in response to an apoptotic stimulus. A higher level of bax/bcl-2 ratio decreases the resistance to apoptotic stimuli, leading to apoptosis. ${ }^{13}$ The bcl-2 protein has an antiapoptotic effect, whereas the bax is known for proapoptotic activity. It has also been well documented that signaling pathway leading to apoptosis involves the sequential activation of cysteine proteases known as caspases. ${ }^{14,15}$

This study was designed to investigate the cytotoxicity of well-characterized $\mathrm{ZnO}$ NPs against three types of cancer cells (human hepatocellular carcinoma HepG2, human lung adenocarcinoma A549, and human bronchial epithelial BEAS-2B) and two primary rat cells (astrocytes and hepatocytes). These cell lines have been extensively utilized in toxicity studies. ${ }^{16-19}$ To explore the underlying molecular mechanisms of apoptosis induced by $\mathrm{ZnO}$ NPs, we have further utilized the human liver cancer HepG2 cells. Quantitative real-time polymerase chain reaction (PCR) and Western blotting techniques were used to determine both the mRNA and protein levels of p53, bax, bcl-2, and caspase-3 genes involved in apoptotic pathways. Reactive oxygen species (ROS) generation and oxidative stress have been proposed as common mediators for apoptosis. ${ }^{20-22}$ Therefore, levels of ROS, lipid peroxidation (LPO), and glutathione (GSH), along with the activity of antioxidant enzymes, were determined. HepG2 cell line was selected because hepatocellular carcinoma is a major health problem, accounting for more than 626,000 new cases per year worldwide. ${ }^{23}$ This cell line has been widely used as a human liver model in the development of new anticancer drugs. ${ }^{24,25}$

\section{Materials and methods Reagents}

Fetal bovine serum, penicillin-streptomycin, DMEM/ F-12 medium, RPMI1640 medium and Dulbecco phosphate buffered saline were purchased from Invitrogen Co, (Carlsbad, CA). MTT (3-(4,5-dimethylthiazol-2-yl)-2, 5-diphenyltetrazoliumbromide), GSH, 5,5-dithio-bis-(2nitrobenzoic acid) (DTNB), thiobarbituric acid (TBA), 2,7dichlorofluorescin diacetate (DCFH-DA), anti-p53 antibody, anti-bax antibody, anti-bcl-2 antibody, and anti- $\beta$-actin antibody were obtained from Sigma-Aldrich (St Louis, MO). Secondary antibodies, RIPA buffer, and sodium dodecyl sulfate (SDS) were bought from Santa Cruz Biotechnology, Inc, (Santa Cruz, CA). All other chemicals used were of the highest purity available from commercial sources.

\section{Synthesis of $\mathrm{ZnO} N P s$}

$\mathrm{ZnONPs}$ were prepared by the coprecipitation technique using highly pure zinc acetate dihydrate $(\mathrm{Zn}[\mathrm{CH} 3 \mathrm{COO}] 2.2 \mathrm{H} 2 \mathrm{O}$, 99\%-100\%, Merck Chemicals, Darmstadt, Germany) as a precursor with sodium hydroxide solution, as described in our previous publication. ${ }^{26}$

\section{Characterization of $\mathrm{ZnO}$ NPs}

The optical absorption of the ZnO NP suspension was measured using a double-beam ultraviolet-visible (UV-Vis) spectrum (Shimadzu-2550, Kyoto, Japan) in the wavelength range of $200-800 \mathrm{~nm}$ at room temperature. The crystalline nature of $\mathrm{ZnO}$ NPs was carried out by X-ray diffraction (XRD) pattern. The XRD pattern of $\mathrm{ZnO}$ nanopowder was acquired at room temperature with the help of a PANalytical X'Pert X-ray diffractometer equipped with an Ni filtered using $\mathrm{Cu} \mathrm{K} \mathrm{K}_{\alpha}(\lambda=1.54056 \AA)$ radiations as an X-ray source. Structural studies of $\mathrm{ZnO}$ NPs were done by field emission scanning electron microscope (JSM-7600F, JEOL Inc, Akishima, Japan) and field emission transmission electron microscopy (JEM-2100F, JEOL Inc,) at an accelerating voltage of $15 \mathrm{kV}$ and $200 \mathrm{kV}$, respectively. Energy-dispersive $\mathrm{X}$-ray spectroscopy (EDS) was utilized to determine the elemental composition (purity) of ZnO NPs.

The average hydrodynamic size and zeta potential of ZnO NPs in water and complete cell culture medium were determined by dynamic light scattering (DLS) (Nano-ZetaSizer-HT, Malvern Instruments, Malvern, UK) as described by Murdock et al. ${ }^{27}$ The ZnO NPs were dispersed in water and complete cell culture medium (DMEM) at a concentration of $15 \mu \mathrm{g} / \mathrm{mL}$ for 24 hours. Then, the suspension was sonicated using a sonicator bath at room temperature for 15 minutes at $40 \mathrm{~W}$ and the DLS experiments performed.

\section{Cell culture and exposure with $\mathrm{ZnO}$ NPs}

Three types of cancer cells (HepG2, A549, and BEAS-2B) and two primary rat cells (astrocytes and hepatocytes) were used to determine the cell viability against ZnO NP exposure. 
Human hepatocellular carcinoma (HepG2) and human bronchial epithelial cells (BEAS-2B) were obtained from American Type Culture Collection (ATCC) (Manassas, VA). Human lung adenocarcinoma (A549) was bought from National Centre for Science (NCCS) (Pune, India). Rat hepatocytes and astrocytes were isolated by collagenase perfusion technique using the method of Moldeus ${ }^{28}$ and Tanaka et al, ${ }^{29}$ respectively.

Cells were cultured in DMEM/F-12 or RPMI 1640 medium supplemented with $10 \%$ fetal bovine serum and $100 \mathrm{U} / \mathrm{mL}$ penicillin-streptomycin at $5 \% \mathrm{CO}_{2}$ and $37^{\circ} \mathrm{C}$. At $85 \%$ confluence, cells were harvested using $0.25 \%$ trypsin and were subcultured into $75 \mathrm{~cm}^{2}$ flasks and six-well plates or 96-well plates according to selection of experiments. Cells were allowed to attach to the surface for 24 hours prior to treatment. $\mathrm{ZnO}$ NPs were suspended in cell culture medium and diluted to appropriate concentrations $(5 \mu \mathrm{g} / \mathrm{mL}, 10 \mu \mathrm{g} / \mathrm{mL}$, and $15 \mu \mathrm{g} / \mathrm{mL})$. The dilutions of $\mathrm{ZnO}$ NPs were then sonicated using a sonicator bath at room temperature for 10 minutes at $40 \mathrm{~W}$ to avoid NP agglomeration prior to cell exposure. Following treatment, cells were harvested to determine cytotoxicity, oxidative stress, and apoptosis markers. Cells not exposed to ZnO NPs served as controls in each experiment. Selection of a $5-15 \mu \mathrm{g} / \mathrm{mL}$ dosage range of $\mathrm{ZnO}$ NPs was based on a preliminary doseresponse study (data not shown).

\section{Cell viability assay}

Viability of HepG2, A549, BEAS-2B, and primary rat cells (hepatocytes and astrocytes) was assessed by the MTT assay as described by Mossman, ${ }^{30}$ with some modifications. ${ }^{15}$ Briefly, $1 \times 10^{4}$ cells/well were seeded in 96-well plates and exposed to $\mathrm{ZnO}$ NPs at the concentrations of $0 \mu \mathrm{g} / \mathrm{mL}$, $5 \mu \mathrm{g} / \mathrm{mL}, 10 \mu \mathrm{g} / \mathrm{mL}$, and $15 \mu \mathrm{g} / \mathrm{mL}$ for 24 hours. At the end of exposure, culture medium was removed from each well to avoid interference of $\mathrm{ZnO}$ NPs and replaced with new medium containing MTT solution $(0.5 \mathrm{mg} / \mathrm{mL})$ in an amount equal to $10 \%$ of culture volume and incubated for 3 hours at $37^{\circ} \mathrm{C}$ until a purple-colored formazan product developed. The resulting formazan product was dissolved in acidified isopropanol. Further, the 96-well plate was centrifuged at $2300 \times \mathrm{g}$ for 5 minutes to settle the remaining $\mathrm{ZnO}$ NPs. Then, a $100 \mu \mathrm{L}$ supernatant was transferred to other fresh wells of a 96-well plate, and absorbance was measured at $570 \mathrm{~nm}$ by a microplate reader (FLUOstar Omega, Cary, NC).

\section{Total RNA isolation and quantitative real- time PCR analysis for apoptotic markers}

Human liver cancer HepG2 cells were cultured in six-well plates and exposed to $15 \mu \mathrm{g} / \mathrm{mL} \mathrm{ZnO}$ NPs for 24 hours. At the end of exposure, total RNA was extracted by RNeasy mini Kit (Qiagen,Valencia, CA, USA) according to the manufacturer's instructions. Concentration of the extracted RNA was determined using Nanodrop 8000 spectrophotometer (ThermoScientific, Wilmington, DE), and the integrity of RNA was visualized on a $1 \%$ agarose gel using a gel documentation system (Universal Hood II, BioRad, Hercules, CA). The first strand of cDNA was synthesized from $1 \mu \mathrm{g}$ of total RNA by reverse transcriptase using M-MLV (Promega, Madison, WI) and oligo (dT) primers (Promega) according to the manufacturer's protocol. Quantitative real-time PCR was performed by QuantiTect SYBR Green PCR kit (Qiagen) using an ABI PRISM 7900HT Sequence Detection System (Applied Biosystems, Foster City, CA). Two microliters of template cDNA was added to the final volume of $20 \mu \mathrm{L}$ of reaction mixture. Real-time PCR cycle parameters included 10 minutes at $95^{\circ} \mathrm{C}$ followed by 40 cycles involving denaturation at $95^{\circ} \mathrm{C}$ for 15 seconds, annealing at $60^{\circ} \mathrm{C}$ for 20 seconds, and elongation at $72^{\circ} \mathrm{C}$ for 20 seconds. The sequences of the specific sets of primer for $\mathrm{p} 53$, bax, bcl-2, caspase-3, and $\beta$-actin used in this study are given in our previous publication. ${ }^{15}$ Expressions of selected genes were normalized to the $\beta$-actin gene, which was used as an internal housekeeping control. All the real-time PCR experiments were performed in triplicate, and data were expressed as the mean of at least three independent experiments.

\section{Western blotting}

Human liver cancer HepG2 cells were cultured in six-well plates and exposed to $\mathrm{ZnO}$ NPs at the concentration of $15 \mu \mathrm{g} / \mathrm{mL}$ for 24 hours. The harvested cell pellets were lysed in RIPA lysis buffer (1X TBS [0.5 MTris- $\mathrm{HCl}$ and $1.5 \mathrm{MNaCl}] \mathrm{pH} 7.4,1 \% \mathrm{NP}-40,0.5 \%$ sodium deoxycholate, $0.1 \%$ SDS, $0.004 \%$ sodium azide) in the presence of a protease inhibitor. The cell lysates were then analyzed for protein content using SDS-Page immunoblotting. The membrane was then probed with $\mathrm{p} 53$, bax, bcl-2, and $\beta$-actin antibodies to determine the expression of proteins.

\section{Caspase- 3 assay}

Activity of caspase-3 enzyme was determined using a standard fluorometric microplate assay. ${ }^{31}$ In brief, $1 \times 10^{4}$ HepG2 cells/well were seeded in a 96-well plate and exposed to $\mathrm{ZnO}$ NPs at the concentration of $15 \mu \mathrm{g} / \mathrm{mL}$ for 24 hours. After the exposure was complete, cells were harvested in icecold phosphate buffer saline and prepared cell lysate. Further, a reaction mixture containing $30 \mu \mathrm{L}$ of cell lysate, $20 \mu \mathrm{L}$ of Ac-DEVDAFC (caspase-3 substrate), and $150 \mu \mathrm{L}$ of protease 
reaction buffer (50 mM Hepes, $1 \mathrm{mM}$ EDTA, and $1 \mathrm{mM}$ DTT) ( $\mathrm{pH}$ 7.2) was incubated for 15 minutes. The fluorescence of the reaction mixture was measured at 5-minute intervals for 15 minutes at excitation/emission wavelengths of $430 / 535 \mathrm{~nm}$ using a microplate reader (FLUOstar Omega). 7-amido-4trifluoromethylcoumarin (AFC) standard ranging from $5 \mu \mathrm{M}$ to $15 \mu \mathrm{M}$ was prepared, and its fluorescence was recorded for calculation of caspase-3 activity in terms of pmol AFC released/minute/mg protein.

\section{Apoptotic DNA ladder assay}

Apoptotic DNA ladder assay was performed in HepG2 cells exposed to $15 \mu \mathrm{g} / \mathrm{mL} \mathrm{ZnO} \mathrm{NPs} \mathrm{for} 24$ hours. At the end of exposure, DNA was extracted using an apoptotic DNA Ladder Kit (Roche, Indianapolis, IN, Cat No. 11835246001). The extracted DNA was then evaluated on a $1 \%$ agarose gel using ethidium bromide. DNA fragmentation pattern was documented by a gel documentation system.

\section{Measurement of intracellular ROS}

Intracellular production of ROS was measured using 2, 7-dichlorofluorescein diacetate (DCFH-DA). ${ }^{32}$ The DCFHDA passively enters the cell, where it reacts with ROS to form the highly fluorescent compound dichlorofluorescein (DCF). In brief, $10 \mathrm{mM}$ DCFH-DA stock solution (in methanol) was diluted in culture medium without serum or another additive to yield a $100 \mu \mathrm{M}$ working solution. HepG2 cells were treated with $\mathrm{ZnO}$ NPs at the concentration of $15 \mu \mathrm{g} / \mathrm{mL}$ for 24 hours. At the end of exposure, cells were washed twice with HBSS and then incubated in $1 \mathrm{~mL}$ of working solution of DCFH-DA at $37^{\circ} \mathrm{C}$ for 30 minutes. Cells were lysed in alkaline solution and centrifuged at $2300 \times \mathrm{g}$ for 10 minutes. A $200 \mu \mathrm{L}$ supernatant was transferred to a 96-well plate, and fluorescence was measured at $485 \mathrm{~nm}$ excitation and $520 \mathrm{~nm}$ emission using a microplate reader (FLUOstar Omega). The values were expressed as a percent of fluorescence intensity relative to control wells.

\section{Assays of oxidative stress parameters}

HepG2 cells were cultured in a $75 \mathrm{~cm}^{2}$ culture flask and exposed to $\mathrm{ZnO}$ NPs at the concentration of $15 \mu \mathrm{g} / \mathrm{mL}$ for 24 hours. After the treatment, cells were washed and harvested in icecold phosphate buffer saline at $4^{\circ} \mathrm{C}$. The harvested cell pellets were then lysed in cell lysis buffer (20 mM Tris- $\mathrm{HCl}$ [pH 7.5], $150 \mathrm{mM} \mathrm{NaCl}, 1 \mathrm{mM}$ Na2EDTA, 1\% Triton and $2.5 \mathrm{mM}$ sodium pyrophosphate). Following centrifugation $(10,000 \times \mathrm{g}$ for 10 minutes at $4^{\circ} \mathrm{C}$ ), the supernatant (cell extract) was maintained on ice until assayed for oxidative stress biomarkers.
The extent of membrane LPO was estimated by measuring the formation of malondialdehyde (MDA) using the method of Ohkawa et al. ${ }^{33} \mathrm{MDA}$ is one of the products of membrane LPO. A mixture of $0.1 \mathrm{~mL}$ cell extract and $1.9 \mathrm{~mL}$ of $0.1 \mathrm{M}$ sodium phosphate buffer ( $\mathrm{pH} 7.4)$ was incubated at $37^{\circ} \mathrm{C}$ for 1 hour. The incubation mixture, after precipitation with $5 \%$ TCA, was centrifuged $(2300 \times \mathrm{g}$ for 15 minutes at room temperature) and the supernatant collected. Then, $1.0 \mathrm{~mL}$ of $1 \%$ TBA was added to the supernatant and placed in the boiling water for 15 minutes. After cooling to room temperature, absorbance of the mixture was taken at $532 \mathrm{~nm}$ and expressed in $\mathrm{nmol} / \mathrm{mg}$ protein using molar extinction coefficient of $1.56 \times 10^{5} \mathrm{M}^{-1} \mathrm{~cm}^{-1}$. GSH level was quantified using Ellman's reagent. ${ }^{34}$ The assay mixture consisted of phosphate buffer, DTNB, and cell extract. The reaction was monitored at $412 \mathrm{~nm}$, and the amount of GSH was expressed in terms of nmol/mg protein. Superoxide dismutase (SOD) activity was estimated by employing a method described earlier. ${ }^{35}$ The assay mixture contained sodium pyrophosphate buffer, nitrobluetetrazolium (NBT), phenazine methosulphate (PMS), reduced nicotinamide adenine dinucleotide (NADH), and the required volume of cell extract. One unit of SOD enzyme activity is defined as the amount of enzyme required for inhibiting the chromogen production (optical density at $560 \mathrm{~nm}$ ) by $50 \%$ in 1 minute under assay conditions and expressed as specific activity in units/mg protein. Catalase (CAT) activity was measured by following its ability to split hydrogen peroxide $\left(\mathrm{H}_{2} \mathrm{O}_{2}\right)$ within 1 minute of incubation time. The reaction was then stopped by adding dichromate/ acetic acid reagent, and the remaining $\mathrm{H}_{2} \mathrm{O}_{2}$ was determined by measuring chromic acetate at $570 \mathrm{~nm}$, which is formed by reduction of dichromate/acetic acid in the presence of $\mathrm{H}_{2} \mathrm{O}_{2}$, as described earlier. ${ }^{36}$ The specific activity of CAT was expressed as unit/mg protein. GSH reductase (GR) activity was measured by following the oxidation of NADPH to $\mathrm{NADP}^{+}$during the reduction of oxidized GSH (GSSG). ${ }^{37}$ GR activity was expressed as nmol NADPH/ minute/mg protein. Activity of GSH peroxidise (GPx) was examined by coupling the reduction of peroxides with GSH and recycling of GSSG by GR in excess using NADPH as a cofactor. ${ }^{38}$ GPx activity was expressed as nmol NADPH/ minute/mg protein.

\section{Estimation of protein}

The total protein content was measured by the Bradford method $^{39}$ using Bradford reagent (Sigma-Aldrich) and bovine serum albumin as the standard. 


\section{Statistical analysis}

Statistical significance was determined by one-way analysis of variance followed by Dunnett's multiple comparison test. Significance was ascribed at $P<0.05$. All analyses were conducted using the Prism software package (GraphPad Software, Version 5.0, GraphPad Software Inc., San Diego, CA).

\section{Results}

\section{Characterization of ZnO NPs}

The UV-Vis spectrum showed a sharp absorption band at $367 \mathrm{~nm}$ (Figure 1). The band-gap energy calculated according to the Mott model ${ }^{40}$ was $3.32 \mathrm{eV}$. The crystal structure of ZnO NPs was characterized by XRD (PANalytical X'Pert Pro $\mathrm{X}$-ray diffractometer) with $\mathrm{Cu} \mathrm{K} \alpha$ radiation $(\lambda=0.15418 \mathrm{~nm})$. Figure 2 shows XRD patterns of $\mathrm{ZnO}$ NPs. The peaks at $2 \theta=31.67^{\circ}, 34.31^{\circ}, 36.14^{\circ}, 47.40^{\circ}, 56.52^{\circ}, 62.73^{\circ}, 66.28^{\circ}$, $67.91^{\circ}, 69.03^{\circ}$, and $72.48^{\circ}$ were assigned to (100), (002), (101), (102), (110), (103), (200), (112), (201), and (004) of $\mathrm{ZnO} \mathrm{NPs}$, indicating that the samples were polycrystalline wurtzite structure (Zincite, JCPDS 5-0664). No characteristic peaks of any impurities were detected, suggesting that highquality ZnO NPs were synthesized. The average crystallite size $(d)$ of $\mathrm{ZnO}$ NPs was estimated by Scherrer's formula: ${ }^{41}$

$$
d=\frac{k \lambda}{\beta \cos \theta}
$$

where $k=0.9$ is the shape factor, $\lambda$ is the $\mathrm{X}$-ray wavelength of $\mathrm{Cu} \mathrm{K \alpha}$ radiation ( $1.54 \AA$ ), $\theta$ is the Bragg diffraction angle, and $\beta$ is the full width at half maximum of the respective diffraction peak.

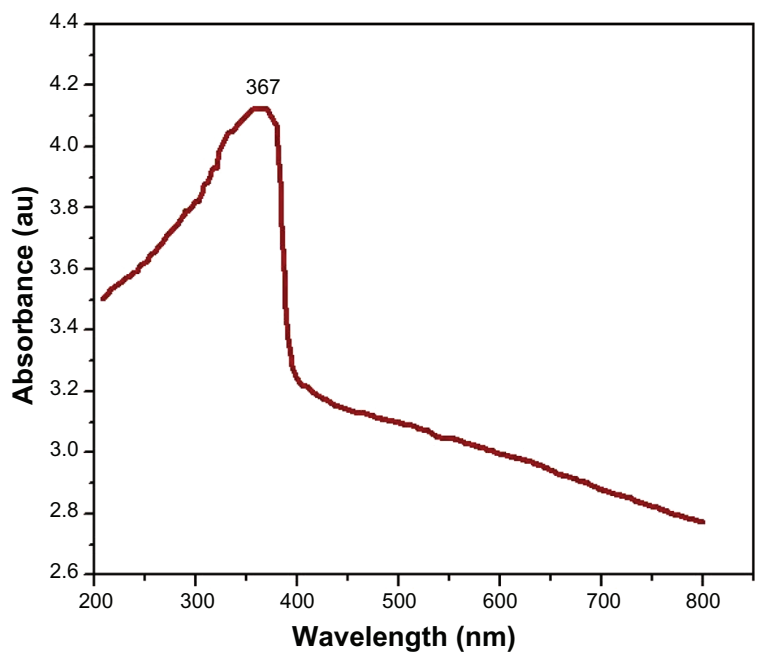

Figure I UV-Visible spectrum of zinc oxide nanoparticles.

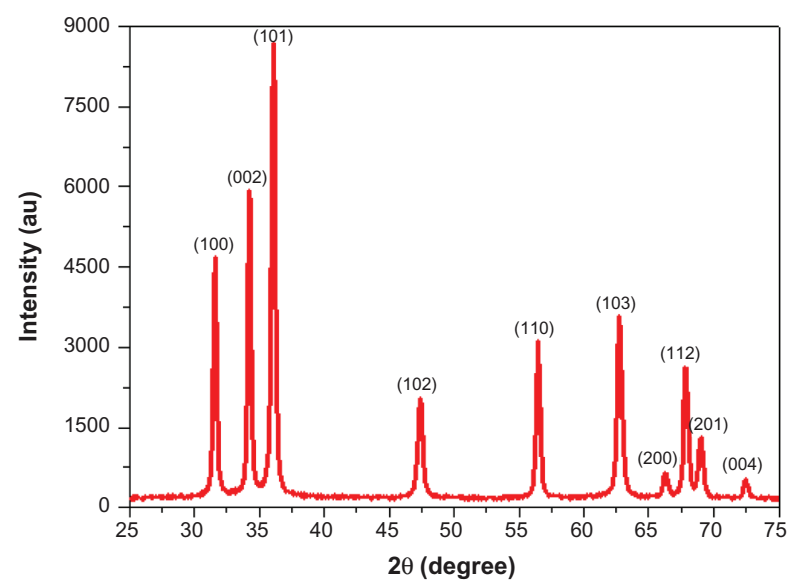

Figure 2 X-ray diffraction pattern of zinc oxide nanoparticles.

The average crystallite size of $\mathrm{ZnO}$ NPs was found to be $21.59 \pm 4.89 \mathrm{~nm}$. Figure $3 \mathrm{~A}$ and B show the typical scanning electron microscopy (SEM) and transmission electron microscopy (TEM) images of the ZnO NPs, respectively. These pictures exhibit that the majority of the particles were a polygonal shape with smooth surfaces. TEM average diameter was calculated from measuring over 100 particles in random fields of TEM view. The average TEM diameter of ZnO NPs was $21.34 \pm 7.67 \mathrm{~nm}$, supporting the XRD data. Figure $3 \mathrm{C}$ represents the frequency of size $(\mathrm{nm})$ distribution of $\mathrm{ZnO}$ NPs. EDS spectrum of $\mathrm{ZnO}$ NPs is given in Figure 3D. The EDS result shows that there are no other elemental impurities present in the synthesized ZnO NPs. The presence of $\mathrm{C}$ and $\mathrm{Cu}$ signals was from the carbon-coated copper TEM grid used in the experiment.

The average hydrodynamic size of ZnO NPs in water and cell culture media determined by DLS was $131 \mathrm{~nm}$ and $127 \mathrm{~nm}$, respectively. Further, the zeta potential of $\mathrm{ZnO}$ NPs in water and culture media was $-31 \mathrm{mV}$ and $-33 \mathrm{mV}$, respectively (Table 1).

\section{Selective killing of cancer cells by $\mathrm{ZnO}$ NPs}

Three types of cancer cells (HepG2, A549, and BEAS-2B) and two types of normal rat cells (astrocytes and hepatocytes) were exposed to $\mathrm{ZnO}$ NPs at the concentrations of $0 \mu \mathrm{g} / \mathrm{mL}$, $5 \mu \mathrm{g} / \mathrm{mL}, 10 \mu \mathrm{g} / \mathrm{mL}$, and $15 \mu \mathrm{g} / \mathrm{mL}$ for 24 hours, and cytotoxicity was determined using MTT assay (Figure 4). Results have shown that $\mathrm{ZnO} N P$ s up to the concentration of $5 \mu \mathrm{g} / \mathrm{mL}$ did not produce a significant reduction in viability of all four types of cancer cells $(P>0.05$ for each). As the concentration of NPs increased to $10 \mu \mathrm{g} / \mathrm{mL}$ and $15 \mu \mathrm{g} / \mathrm{mL}$, a significant reduction in cell viability was observed for all cancer cells in 

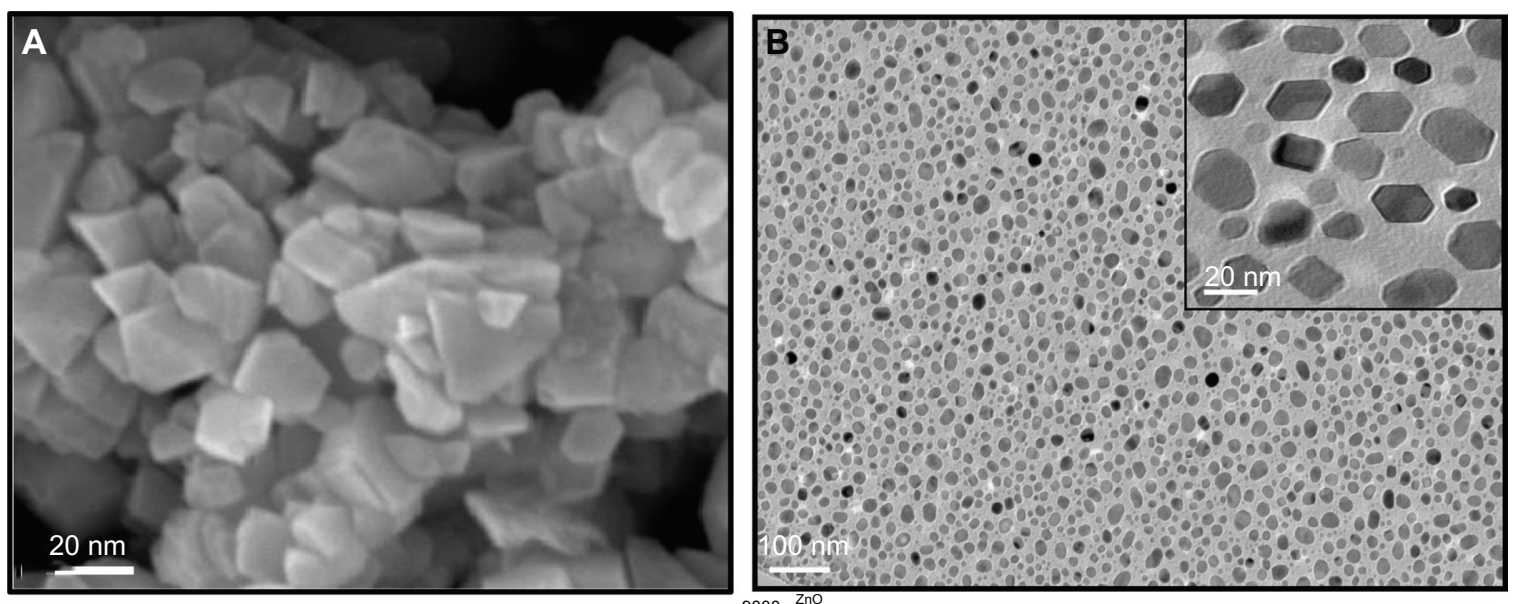

C
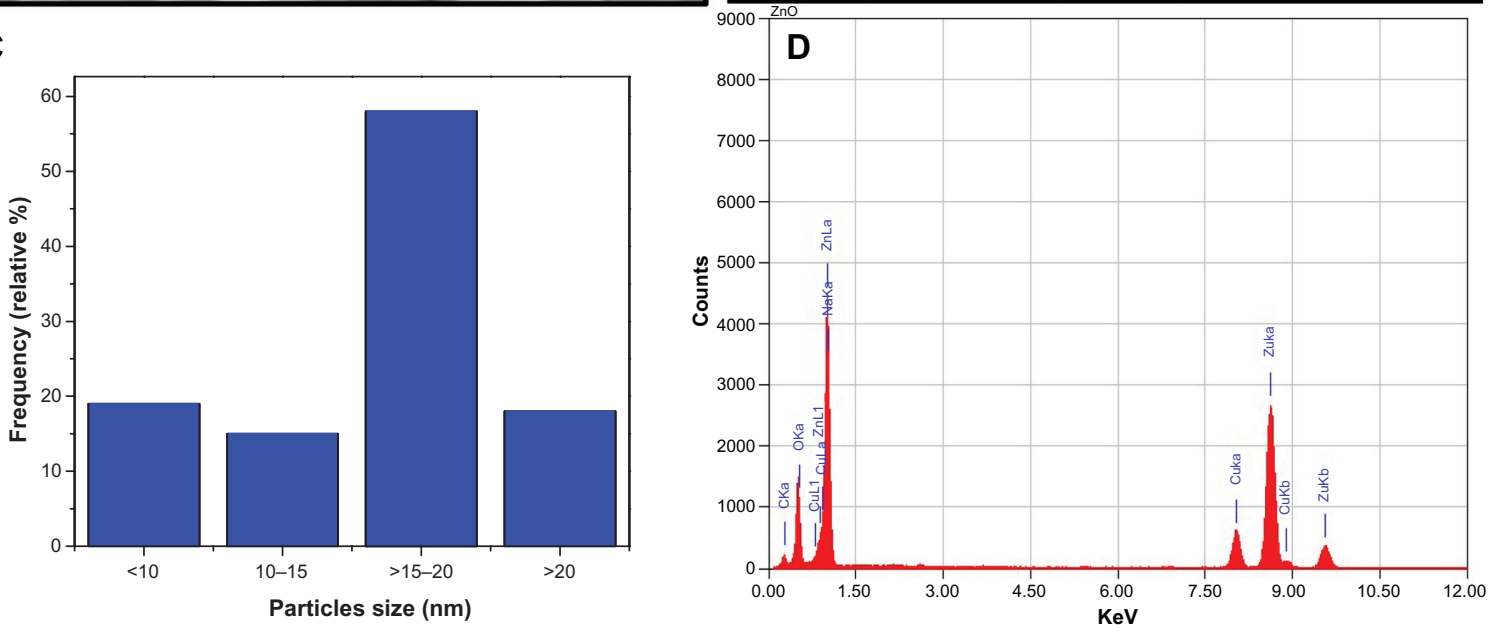

Figure 3 Electron microscopy characterization of zinc oxide nanoparticles. (A) Field emission scanning electron microscope image, (B) field emission transmission electron microscopy image (inset with higher magnification), (C) frequency of size distribution, and (D) energy-dispersive X-ray spectroscopy spectrum.

a dose-dependent manner ( $P<0.05$ for each). At $15 \mu \mathrm{g} / \mathrm{mL}$, cell viability was significantly decreased to $33 \%, 39 \%$, and $47 \%$ for the BEAS-2B, HepG2, and A549 cells, respectively $(P<0.05$ for each). However, $\mathrm{ZnO}$ NPs did not induce a significant reduction in the viability of primary rat astrocytes and hepatocytes up to the maximum concentration $(15 \mu \mathrm{g} / \mathrm{mL})$ used in this study (Figure 4).

\section{$\mathrm{ZnO}$ NPs altered the expression of mRNA levels of apoptotic genes in human liver cancer HepG2 cells}

Quantitative real-time PCR was used to analyze the mRNA levels of apoptotic genes (p53, bax, bcl-2, and caspase-3)

Table I Dynamic light scattering characterization of zinc oxide nanoparticles

\begin{tabular}{lll}
\hline & Water & Culture medium \\
\hline Hydrodynamic size $(\mathrm{nm})$ & $\mathrm{I} 3 \mathrm{|}$ & 127 \\
Zeta potential $(-\mathrm{mV})$ & 31 & 33 \\
\hline
\end{tabular}

in HepG2 cells exposed to $\mathrm{ZnO}$ NPs at the concentration of $15 \mu \mathrm{g} / \mathrm{mL}$ for 24 hours. Results showed that $\mathrm{ZnO}$ NPs significantly altered the expression levels of mRNA of these genes in HepG2 cells. The mRNA expression level of tumor suppressor gene p53 (Figure 5A) and proapoptotic gene bax (Figure 5B) were significantly upregulated while the expression of antiapoptotic gene bcl-2 (Figure 5C) was significantly downregulated in $\mathrm{ZnO}$ NP-treated cells as compared with the untreated control cells. We further observed that the mRNA expression of caspase-3 enzyme, another marker of apoptosis, was significantly higher in $\mathrm{ZnO}$ NP-treated cells than those of the untreated control cells (Figure 5D) $(P<0.05$ for each).

\section{$\mathrm{ZnO}$ NPs altered the expression of protein levels of apoptotic genes in human liver cancer HepG2 cells}

To confirm the quantitative real-time PCR results, we further examined the expression of protein levels in $\mathrm{ZnO} \mathrm{NP-exposed}$ HepG2 cells using immunoblotting. Similar to mRNA 


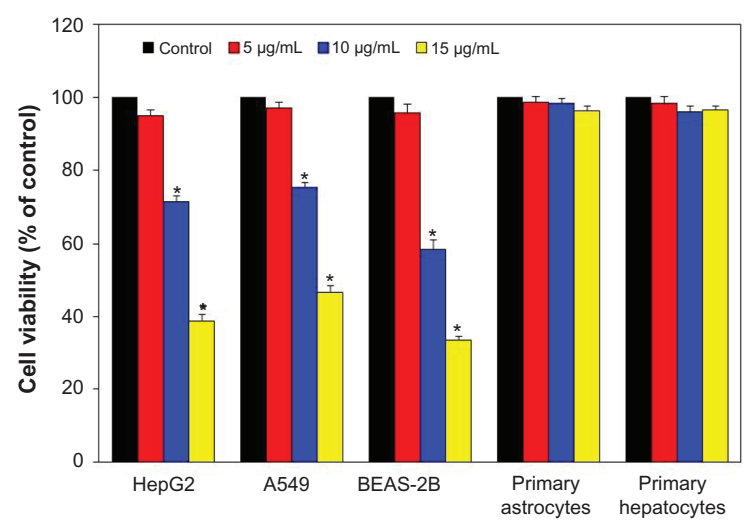

Figure 4 Effect of zinc oxide nanoparticles on the viability of three types of cancer cells (HepG2,A549, and BEAS-2B) and two types of normal cells (rat astrocytes and hepatocytes). Cells were treated with zinc oxide nanoparticles at the concentrations of $0 \mu \mathrm{g} / \mathrm{mL}, 5 \mu \mathrm{g} / \mathrm{mL}, 10 \mu \mathrm{g} / \mathrm{mL}$, and $15 \mu \mathrm{g} / \mathrm{mL}$ for 24 hours. At the end of exposure, cell viability was determined using MTT assay, as described in Materials and methods. Data represented are mean \pm standard deviation of three identical experiments made in triplicate.

Note: *Statistically significant difference as compared with the controls $(P<0.05$ for each).

results, the protein levels of p53 and bax were significantly upregulated while the expression of bcl-2 was significantly downregulated in $\mathrm{ZnO}$ NP-treated cells (Figure 6A and B) $(P<0.05$ for each). Activity of caspase- 3 enzyme was also significantly higher in $\mathrm{ZnO}$ NP-exposed cells compared with in control cells (Figure 6C) $(P<0.05)$.
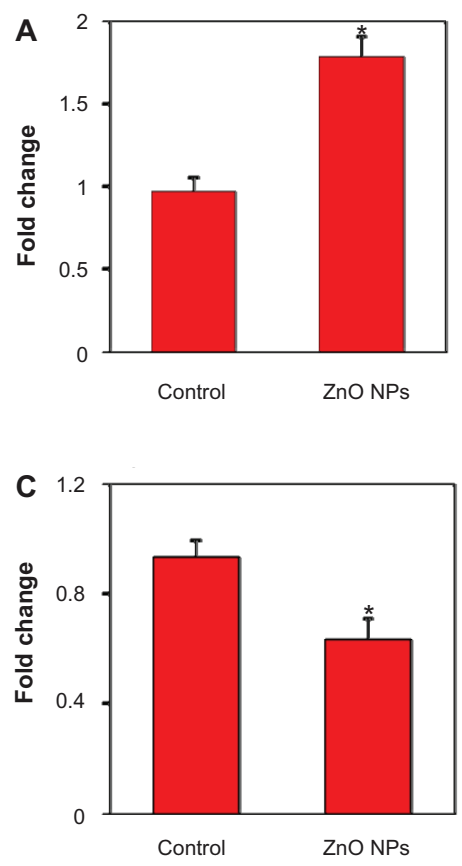

\section{ZnO NPs induced apoptotic DNA fragmentation in human liver cancer HepG2 cells}

The DNA profiles of the cells treated with $15 \mu \mathrm{g} / \mathrm{mL}$ of $\mathrm{ZnO}$ NPs for 24 hours along with untreated control cells were analyzed. In control cells, the DNA was not fragmented, whereas the cells treated with $\mathrm{ZnO}$ NPs had started the apoptotic process, as was evident by DNA fragmentation (Figure 6D).

\section{$\mathrm{ZnO}$ NPs altered the oxidant/ antioxidant balance of human liver cancer HepG2 cells}

It has been suggested that oxidant generation and antioxidant depletion are the common pathways through which anticancer drugs trigger apoptosis in cancer cells. ${ }^{22}$ Therefore, the status of oxidants and antioxidants was examined in human liver cancer HepG2 cells treated with ZnO NPs at the concentration of $15 \mu \mathrm{g} / \mathrm{mL}$ for 24 hours. ROS and LPO levels were measured as markers of oxidants, whereas antioxidant status was examined by determining the GSH, SOD, CAT, GPx, and GR. Results showed that oxidant (ROS and LPO) levels were significantly higher in treated cells (Figure 7A and B)
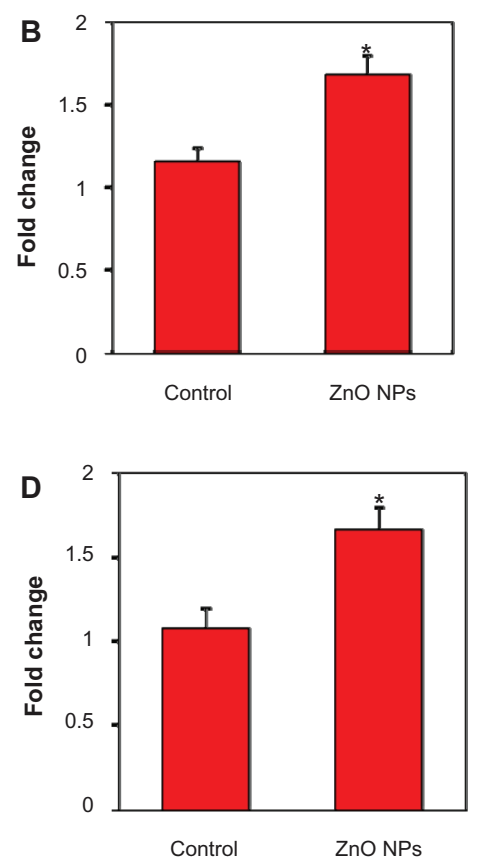

Figure 5 Quantitative real-time polymerase chain reaction analysis of mRNA levels of apoptotic genes in human lung cancer (HepG2) cells treated with zinc oxide nanoparticles (ZnO NPs) at the concentration of $15 \mu \mathrm{g} / \mathrm{mL}$ for 24 hours. Quantitative real-time polymerase chain reaction was performed by QuantiTect SYBR Green PCR kit using an ABI PRISM 7900HT sequence detection system. The $\beta$-actin was used as the internal control to normalize the data. ZnO NP-induced alterations in mRNA levels are expressed in relative quantity compared with those for the respective unexposed control cells. (A) p53, (B) bax, (C) bcl-2, and (D) caspase-3. Data represented are mean \pm standard deviation of three identical experiments made in triplicate.

Note: $*$ Statistically significant difference as compared with the controls $(P<0.05$ for each). 
A

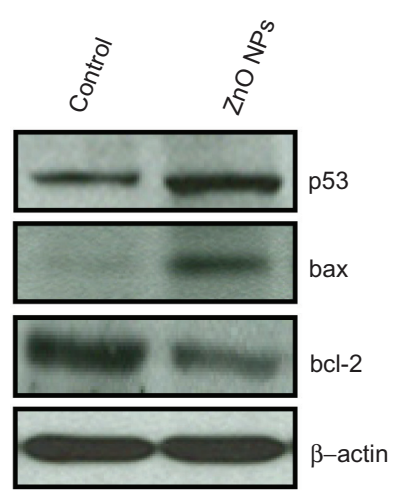

C

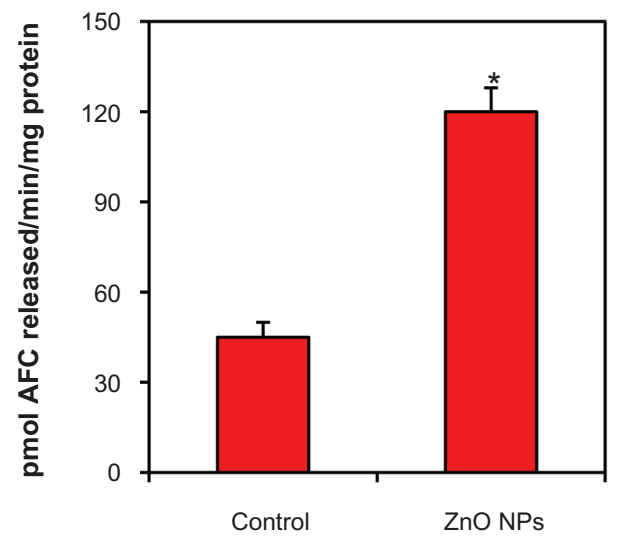

B
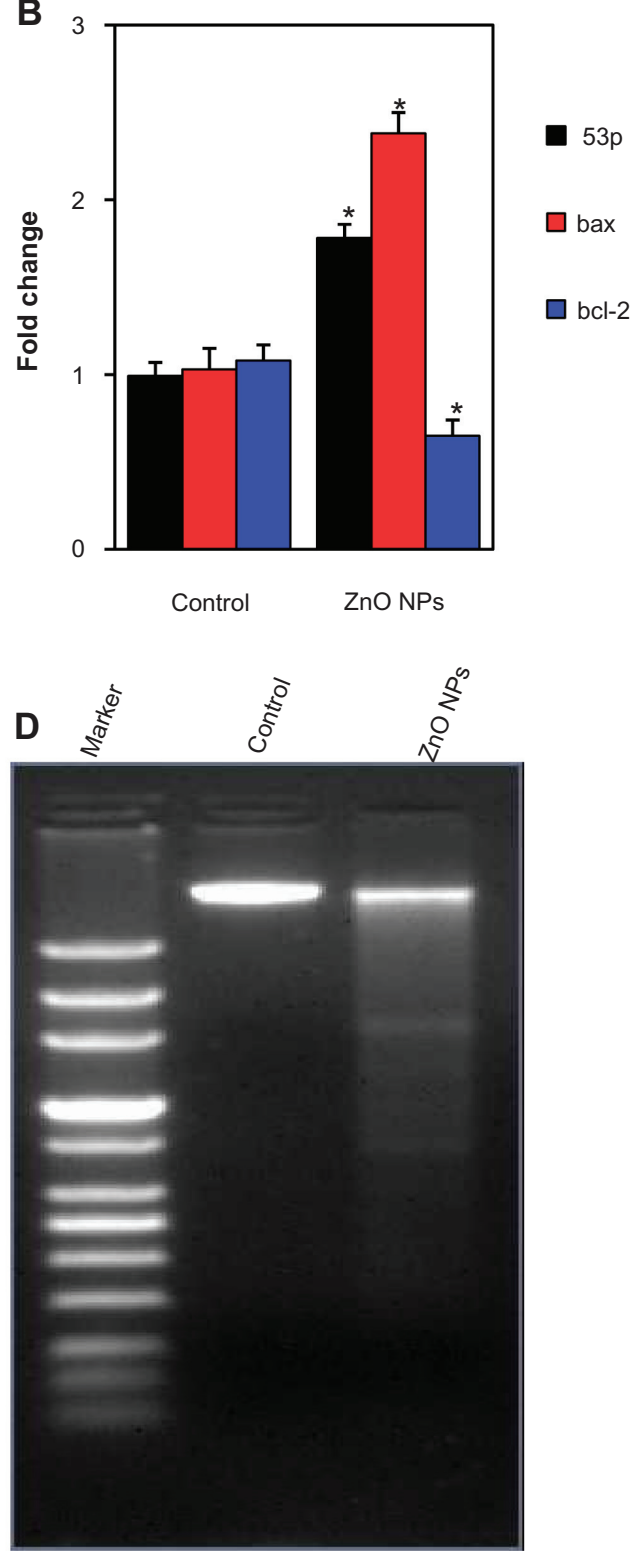

Figure 6 Zinc oxide nanoparticles (ZnO NPs) induced apoptosis in human lung cancer (HepG2) cells. (A) Western blot analysis of p53, bax, bcl-2, and bax proteins in HepG2 cells treated with $15 \mu \mathrm{g} / \mathrm{mL}$ ZnO NPs for 24 hours. At the end of exposure, cells were lysed in RIPA buffer and cell extract subjected to Western blots antibodies, as described in Materials and methods. Immunoblot images are the representative of three identical experiments. The $\beta$-actin blot is a loading control. (B) Protein levels were also analyzed by desitometric analysis using AlphaEase TM FC StandAlone V.4.0.0 software. Results are expressed as a fold change over the control group. Bar diagrams are from mean \pm standard deviation of protein levels from three blots. (C) ZnO NPs induced the activity of Caspase-3 enzyme in HepG2 cells. Caspase-3 data represented are mean \pm standard deviation of three identical experiments made in triplicate. (D) ZnO NPs induced the apoptotic DNA fragmentation in HepG2 cells treated with I5 $\mu \mathrm{g} / \mathrm{mL}$ $\mathrm{ZnO}$ NPs for 24 hours.

Note: *Statistically significant difference as compared to the controls $(P<0.05$ for each).

$(P<0.05$ for each). On the other hand, ZnO NPs induced GSH depletion (Figure 8A) along with the lower activity of antioxidant enzymes GPx, GR, SOD, and CAT in HepG2 cells (Figure $8 \mathrm{~B}-\mathrm{E})(P<0.05$ for each).

\section{Discussion}

Nanomedicine aims to overcome the problems related to human diseases at the nanoscale level, where most of the biological molecules exist and operate..$^{42}$ Physicochemical characterization of nanoscale materials is essential in biomedical research for better interpretation of results. Parameters including shape, size, crystal structure, purity, hydrodynamic size, agglomeration, and aqueous stability have been suggested for NP characterization. ${ }^{20} \mathrm{UV}$-Vis spectroscopy, XRD, SEM, TEM, EDS, and DLS techniques were utilized to characterize the NPs. The band-gap energy 

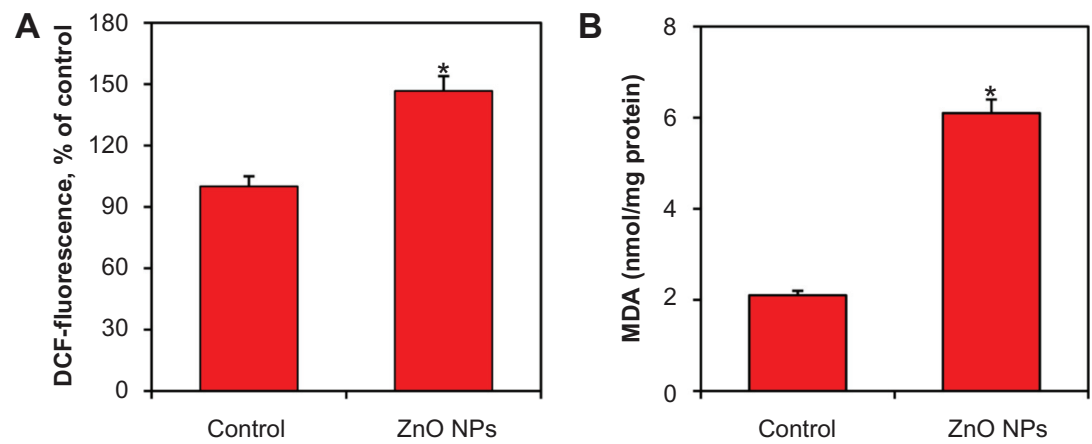

Figure 7 Zinc oxide nanoparticles (ZnO NPs) induced oxidant generation in human lung cancer (HepG2) cells treated with $15 \mu \mathrm{g} / \mathrm{mL} \mathrm{ZnO}$ NPs for 24 hours. At the end of treatment, reactive oxygen species (ROS) and malondialdehyde (MDA) levels were determined, as described in Materials and methods. (A) ROS and (B) MDA. Data represented are mean \pm standard deviation of three identical experiments made in triplicate.

Note: *Statistically significant difference as compared to the controls $(P<0.05$ for each).

calculated from the UV-Vis spectrum of the ZnO NPs was $3.32 \mathrm{eV}$. It has been suggested that due to a wide band gap (energy donor capacity), ZnO NPs could act as novel photosensitizers, or at least as potentiators of the conventional photosensitizing drugs, in photodynamic therapy of cancer. ${ }^{43}$ Recent studies reported that UV irradiation could readily enhance the proliferation-suppression ability of ZnO NPs on cancer cells. ${ }^{43,44}$ Our XRD results confirm the crystalline nature of ZnO NPs. SEM and TEM showed that NPs were polygonal in shape with a smooth surface, were fairly distributed, and had an average diameter of $21 \mathrm{~nm}$. EDS data indicated that synthesized $\mathrm{ZnO}$ NPs were highly pure with no traces of impurities. Agglomeration and stability of NPs in an aqueous state are major concerns in nanomedicine research. Once the $\mathrm{ZnO}$ NPs were introduced to water or cell culture media, the sizes changed to approximately five
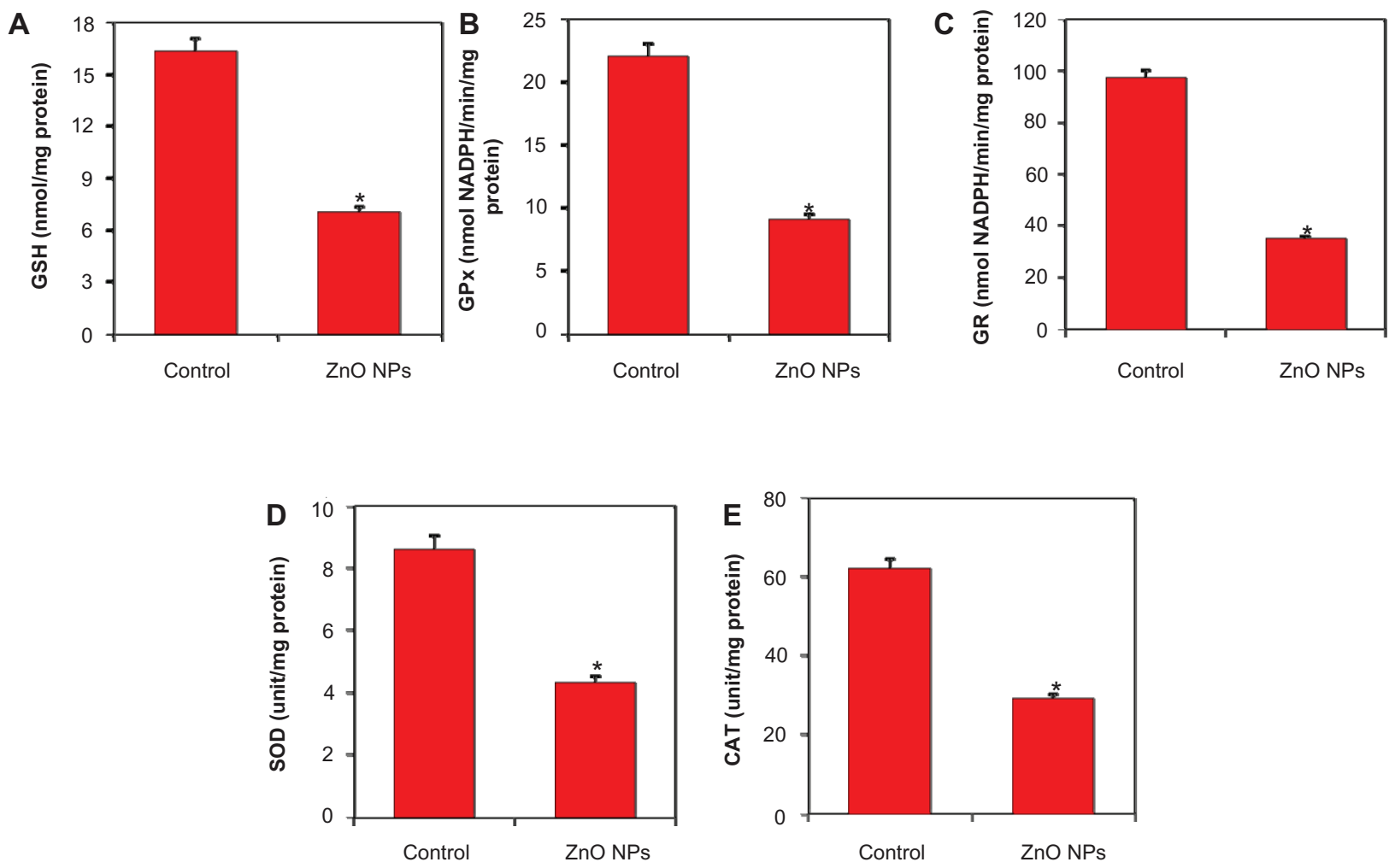

Figure 8 Zinc oxide nanoparticles (ZnO NPs) diminished the antioxidant defense system of human lung cancer (HepG2) cells treated with I5 $\mu$ g/mL ZnO NPs for 24 hours. At the end of treatment, glutathione (GSH) level and antioxidant enzyme activity were determined, as described in Materials and methods. (A) GSH, (B) GSH peroxidise (GPx), (C) GSH reductase (GR), (D) superoxide dismutase (SOD), and (E) catalase (CAT). Data represented are mean \pm standard deviation of three identical experiments made in triplicate.

Note: *Statistically significant difference as compared to the controls $(P<0.05$ for each). 
to ten times the primary size. ${ }^{45}$ The average hydrodynamic size of the present $\mathrm{ZnO}$ NPs in water and cell culture media determined by DLS was $131 \mathrm{~nm}$ and $127 \mathrm{~nm}$, respectively. The higher size of NPs in aqueous suspension as compared with TEM and XRD might be due to the tendency of particles to agglomerate in an aqueous state. This finding is supported by other investigators ${ }^{27,46}$ and has been briefly discussed in our previous publications. ${ }^{47,48}$ The tendency of particles to form aggregates depends strongly on the surface charge. The particle charge, determined as zeta potential, was $-31 \mathrm{mV}$ and $-33 \mathrm{mV}$ for water and culture medium, respectively. Zeta potential results suggested that ZnO NPs are fairly stable in an aqueous state.

One of the major challenges in cancer therapy is to improve the selectivity and efficacy of anticancer drugs and reduce their side effects to improve quality of life for cancer patients. ${ }^{49}$ The key finding of this investigation was to support the hypothesis that ZnO NPs induce toxicity in a cell-specific manner. We have observed that ZnO NPs have distinct effects on mammalian cell viability via killing cancer cells (HepG2, A549, and BEAS-2B) while posing no impact on normal cells like rat astrocytes and hepatocytes. Our cytotoxicity results are in agreement with recently published studies that reported that $\mathrm{ZnO}$ NPs significantly induce cytotoxicity to cancer cells, and no major effect was observed on normal cells. Ostrovsky et $\mathrm{al}^{8}$ have reported that the $\mathrm{ZnO}$ NPs exerted cytotoxic effect on several human glioma cell lines (A172, U87, LNZ308, LN18, and LN229), and no cytotoxic effect was observed on normal human astrocytes. ZnO NPs exhibited a preferential ability to kill human myeloblastic leukemia cells (HL60) as compared with normal peripheral blood mononuclear cells. ${ }^{9}$ Hanley et $\mathrm{al}^{7}$ also observed that $\mathrm{ZnO}$ NPs exhibit a strong preferential ability to kill cancerous $T$ cells compared with normal cells. Selective killing of cancer cells by ZnO NPs may be of important clinical interest, as one of the greatest challenges facing cancer chemotherapy is the inability of anticancer drugs to effectively distinguish between normal and cancer cells.

The shape of NPs also plays a significant role in the killing of cancer cells. Nair et $\mathrm{al}^{50}$ showed that rod-shaped $\mathrm{ZnO}$ NPs exerted lower cytotoxicity as compared with spherical $\mathrm{ZnO}$ NPs in osteoblast cancer cells. In the present study we observed that polygonal $\mathrm{ZnO}$ NPs seem to be much more cytotoxic to cancer cells than previously reported rod-shaped $\mathrm{ZnO}$ NPs. ${ }^{18}$ Polygonal $\mathrm{ZnO}$ NPs at the concentration of $15 \mu \mathrm{g} / \mathrm{mL}$ decreased the cell viability to $33 \%, 39 \%$, and $47 \%$ for the BEAS-2B, HepG2, and A549 cells, respectively, whereas our previous study showed that $100 \mu \mathrm{g} / \mathrm{mL}$ of rod-shaped $\mathrm{ZnO}$ NPs was required to reduce $27 \%$ viability of A549 cancer cells with the same exposure time. It is also worth mentioning that present polygonal $\mathrm{ZnO}$ NPs were synthesized by the coprecipitation method, and previously reported rod-shaped $\mathrm{ZnO}$ NPs were prepared with the sol-gel technique using the same precursor, zinc acetate dihydrate.

We should further consider the stability of the particles in cell culture suspension as well as potential concerns about the toxicity of dissolved $\mathrm{Zn}^{2+}$ ions. Recent studies have shown that $\mathrm{Zn}^{2+}$ is released from the surface of $\mathrm{ZnO}$ NPs when they are suspended in an aqueous state. ${ }^{46,51}$ However, in the present study, we did not examine the degree of ionization of $\mathrm{ZnO}$ NPs in an aqueous suspension and their toxicity to cancer cells. Several recent studies, along with our previous publication, showed that $\mathrm{ZnO}$ NPs liberate $\mathrm{Zn}^{2+}$ in an aqueous state, but the levels of $\mathrm{Zn}^{2+}$ released were insufficient to promote toxicity to cells unless the particulate matter is in contact with the cells. ${ }^{18,52,53}$ Moreover, in a recent investigation, Kilari et $\mathrm{al}^{54}$ showed the protective effect of $\mathrm{Zn}^{2+}$ in colon cancer (Caco-2) cells.

We utilized human liver cancer (HepG2) to explore the possible molecular mechanisms of toxicity induced by $\mathrm{ZnO}$ NPs. We observed that the expressions of both mRNA and protein levels of tumor suppressor gene $\mathrm{p} 53$ and proapoptotic genes (bax and caspase-3) were upregulated while the expression of antiapoptotic gene bcl-2 was downregulated in cancer cells treated with $\mathrm{ZnO}$ NPs. In the presence of DNA damage or cellular stress, p53 triggers cell-cycle arrest to provide time for the damage to be repaired or for self-mediated apoptosis. ${ }^{12}$ Gopinath et $\mathrm{l}^{55}$ also showed that bax is upregulated by $\mathrm{p} 53$. Because an increase in bax expression was observed in this study, the role of p53 in the upregulation of bax upon $\mathrm{ZnO}$ NP treatment can be postulated. Cleavage of DNA at the internucleosomal linker sites yielding DNA fragments is regarded as a biochemical hallmark of apoptosis. ${ }^{56}$ Activated caspase- 3 is capable of autocatalysis as well as cleaving and activating other members of the caspase family, leading to rapid and irreversible apoptosis. ${ }^{57}$ In the present study we also showed the higher activity of caspase-3 enzyme along with the DNA fragmentation in liver cancer cells treated with $\mathrm{ZnO}$ NPs. Consequently, ZnO NPs show much promise as new anticancer agents, given the specific apoptotic response of cancer cells, as shown in this work. However, the exact difference that resulted in cancer-specific toxicity is still largely unclear.

Current developments in cancer research suggest that a number of apoptotic stimuli share common mechanistic pathways characterized by the generation of ROS through 
oxidative stress..$^{22,48,58}$ ROS typically include the superoxide radical $\left(\mathrm{O}^{2-}\right)$, hydrogen peroxide $\left(\mathrm{H}_{2} \mathrm{O}_{2}\right)$, and hydroxyl radical $(\mathrm{OH})$, which cause damage to cellular components including DNA and proteins. ${ }^{21}$ In the present study, ZnO NPs significantly altered the oxidant/antioxidant status of human liver cancer cells. ROS generation and membrane LPO were significantly higher, whereas antioxidant molecule GSH and the activity of antioxidant enzymes SOD, CAT, GPx, and GR were significantly lower in ZnO NP-treated cells. GSH, a ubiquitous and abundant cellular antioxidant tripeptide, was found to be strongly depleted in response to NP treatment. ${ }^{59}$ GR is an important enzyme in recycling the GSSH back to GSH. The activity of GPx can provide important clues about the consumption rate of GSH during detoxification of organic hydroperoxides by it. SOD is specialized to convert highly reactive $\mathrm{O}^{2-}$ to less toxic $\mathrm{H}_{2} \mathrm{O}_{2}$. CAT enzyme reduces $\mathrm{H}_{2} \mathrm{O}_{2}$ to $\mathrm{H}_{2} \mathrm{O}^{60,61}$ Higher production of intracellular ROS and membrane LPO in ZnO NP-treated cancer cells, along with depletion of antioxidant components, suggests that ROS generation and oxidative stress might be the primary mechanisms for toxicity of $\mathrm{ZnO}$ NPs to human liver cancer HepG2 cells.

\section{Conclusion}

We observed that ZnO NPs have distinct effects on mammalian cell viability via killing cancer cells (HepG2, A549, and BEAS-2B) while posing no effect on normal cells (rat astrocytes and hepatocytes). The marked difference in cytotoxicity between cancer cells and normal cells suggests an exciting potential for $\mathrm{ZnO}$ NPs as novel alternatives to cancer therapy. Our molecular data showed that both mRNA and protein levels of tumor suppressor gene p53 and apoptotic gene bax were upregulated while the antiapoptotic gene bcl-2 was downregulated in $\mathrm{ZnO}$ NP-treated human liver cancer cell HepG2. ZnO NPs were also found to induce activity of caspase-3 enzyme and DNA fragmentation in HepG2 cells. Moreover, ZnO NPs induced levels of oxidants (ROS and LPO) and reduced the antioxidant capacity of HepG2 cells. This study suggests that $\mathrm{ZnO}$ NPs induce apoptosis in cancer cells, which is mediated by ROS via p53, bax/bcl-2, and caspase pathways through which most of the anticancer drugs trigger apoptosis. Further research on other cancer cells and normal cells must be considered to determine whether this is a universal mechanism in the anticancer activity of $\mathrm{ZnO}$ NPs.

\section{Acknowledgments}

The authors are thankful to King Abdulaziz City for Science and Technology (KACST), Riyadh, Saudi Arabia, for research funding under the National Plan for Science and Technology (NPST) (Grant No. 10-NAN1201-02).

\section{Disclosure}

The authors report no conflicts of interest in this work.

\section{References}

1. Lee JH, Huh YM, Jun YW, Seo JW, Jang JT, Song HT, et al. Artificially engineered magnetic nanoparticles for ultra-sensitive molecular imaging. Nat Med. 2007;13:95-99.

2. Wang ZL. Splendid one-dimensional nanostructures of zinc oxide: a new nanomaterial family for nanotechnology. ACS Nano. 2008;2:1987-1992.

3. Visaria RK, Griffin RJ, Williams BW, Ebbini ES, Paciotti GF, Song CW, et al. Enhancement of tumor thermal therapy using gold nanoparticleassisted tumor necrosis factor- $\alpha$ delivery. Mol Cancer Ther. 2006;5: 1014-1020.

4. Wang L, Liu Y, Li W, Jiang X, Ji Y, Wu X, et al. Selective targeting of gold nanorods at the mitochondria of cancer cells: implications for cancer therapy. Nano Lett. 2011;11:772-780.

5. Wu Y-N, Chen D-H, Shi X-Y, Lian C-C, Wang T-Y, Yeh C-S, et al. Cancer-cell-specific cytotoxicity of non-oxidized iron elements in iron core-gold shell NPs. Nanomedicine: NBM. 2011;7:420-427.

6. Zhang H, Chen B, Jiang H, Wang C, Wang H, Wang X. A strategy for $\mathrm{ZnO}$ nanorod mediated multi-mode cancer treatment. Biomaterials. 2011;32:1906-1914.

7. Hanley C, Layne J, Punnoose A, Reddy KM, Coombs I, Coombs A, et al. Preferential killing of cancer cells and activated human T cells using ZnO nanoparticles. Nanotechnology. 2008;19:295103.

8. Ostrovsky S, Kazimirsky G, Gedanken A, Brodie C. Selective cytotoxic effect of $\mathrm{ZnO}$ nanoparticles on glioma cells. Nano Res 2009;2:882-890.

9. Premanathan M, Karthikeyan K, Jeyasubramanian K, Manivannan G. Selective toxicity of $\mathrm{ZnO}$ nanoparticles toward Gram positive bacteria and cancer cells by apoptosis through lipid peroxidation. Nanomedicine: NBM. 2011;7:184-192.

10. Sherr CJ. Principles of tumor suppression. Cell. 2004;11:235-246.

11. Ahamed M, Karns M, Goodson M, Rowe J, Hussain S, Schlager J, et al. DNA damage response to different surface chemistry of silver nanoparticles in mammalian cells. Toxicol Appl Pharmacol. 2008;233:404-410.

12. Farnebo M, Bykov VN, Wiman KG. The p 53 tumor suppressor: a master regulator of diverse cellular processes and therapeutic target in cancer. Biochem Biophys Res Commun. 2010;396:85-89.

13. Chougule M, Patel AR, Sachdeva P, Jackson T, Singh M. Anticancer activity of Noscapine, an opioid alkaloid in combination with cisplatin in human non-small cell lung cancer. Lung Cancer. 2010. doi:10.1016/j. lungcan.2010.06.002.

14. Tang X, Guo Y, Nakamura K, Huang H, Hamblin M, Chang L, et al. Nitro-alkenes induce rat aortic smooth muscle cell apoptosis via activation of caspase-dependent pathways. Biochem Biophys Res Commun. 2010;397:239-244.

15. Ahamed M, Akhtar MJ, Siddiqui MA, Ahmad J, Musarrat J, AlKhedhairy AA, et al. Oxidative stress mediated apoptosis induced by nickel ferrite nanoparticles in cultured A549 cells. Toxicology. 2011;283:101-108.

16. Shi Y, Wang F, He J, Yadav S, Wang H. Titanium dioxide nanoparticles cause apoptosis in BEAS-2B cells through the caspase 8/t-Bid-independent mitochondrial pathway. Toxicol Lett. 2010;196: 21-27.

17. Ahmad I, Siddiqui H, Akhtar MJ, Khan MI, Patil G, Ashquin M, et al. Toxic responses in primary rat hepatocytes exposed with occupational dust collected from work environment of bone-based industrial unit. Chemosphere. 2011;83:455-460. 
18. Ahamed M, Akhtar MJ, Raja M, Ahmad I, Siddiqui MKJ, AlSalhi MS, et al. Zinc oxide nanorod induced apoptosis via p53, bax/bcl-2 and survivin pathways in human lung cancer cells: role of oxidative stress. Nanomedicine: NBM. 2011;7:904-913.

19. Akhtar MJ, Ahamed M, Fareed M, Alrokayan SA, Kumar S. Protective effect of sulphoraphane against oxidative stress mediated toxicity induced by $\mathrm{CuO}$ nanoparticles in mouse embryonic fibroblasts BALB 3T3. J Toxicol Sci. 2011 Accepted.

20. Nel A, Xia T, Madler L, Li N. Toxic potential of materials at the nanolevel. Science. 2006;311:622-627.

21. Ott M, Gogvadze V, Orrenius S, Zhivotovsky B. Mitochondria, oxidative stress and cell death. Apoptosis. 2007;12:913-922.

22. Yip NC, Fombon IS, Liu P, Brown S, Kannappan V, Armesilla AL, et al. Disulfiram modulated ROS-MAPK and NFKB pathways and targeted breast cancer cells with cancer stem cell-like properties. British J Cancer. 2011;104:1564-1574.

23. Parkin DM, Bray F, Ferlay J, Pisani P. Global cancer statistics, 2002. Cancer J Clin. 2005;55:74-108.

24. Cao J, Liu Y, Jia L, Zhou HM, Kong Y, Yang G. Curcumin induces apoptosis through mitochondrial hyperpolarization and mtDNA damage in human hepatoma G2 cells. Free Radic Biol Med. 2007;43:968-975.

25. Lu X, Qian J, Zhou H, Gan Q, Tang W, Lu J, et al. In vitro cytotoxicity and induction of apoptosis by silica nanoparticles in human HepG2 hepatoma cells. Int J Nanomed. 2011;6:1889-1901.

26. Khan MAM, Khan MW, Alhoshan M, AlSalhi MS, Aldwayyan A. Influences of Co doping on the structural and optical properties of $\mathrm{ZnO}$ nanostructured. Appl Phys A. 2011;100:45-51.

27. Murdock RC, Braydich-Stolle L, Schrand AM, Schlager JJ, Hussain SM. Characterization of nanomaterial dispersion in solution prior to in vitro exposure using dynamic light scattering technique. Toxicol Sci. 2007;101:239-253.

28. Moldeus P. Isolation and use of liver cells. In: Fleischer S, Pscker L, editors. Methods in Enzymology. New York, Academic Press; 1978:60.

29. Tanaka J, Toku K, Matsuda S, Sudo S, Fujita H, Sakanaka M, et al. Induction of resting microglia in culture medium devoid of glycine and serine. Glia. 1998;24:198-215.

30. Mossman T. Rapid colorimetric assay for cellular growth and survival: application to proliferation and cytotoxicity assays. J Immunol Meth. 1983;65:55-63

31. Walsh JG, Cullen SP, Sheridan C, Luthi AU, Gerner C, Martin SJ. Executioner caspase-3 and caspase-7 are functionally distinct proteases. PNAS. 2008;105:12815-12819.

32. Wang H, Joseph JA. Quantifying cellular oxidative stress by dichlorofluorescein assay using microplate reader. Free Radic Biol Med. 1999;27:612-616.

33. Ohkawa H, Ohishi N, Yagi K. Assay for lipid peroxides in animal tissues by thiobarbituric acid reaction. Anal Biochem. 1979;95:351-358.

34. Ellman G1. Tissue sulfhydryl groups. Arch Biochem Biophys. 1959;82:70-77.

35. Kakkar PS, Das B, Viswanathan PN. A modified spectrophotometric assay of superoxide dismutase. Ind J Biochem Biophys. 1984;21:130-132.

36. Sinha AK. Colorimetric assay of catalase. Anal Biochem. 1972;47:389-394.

37. Goldberg DM, Spooner RJ. Glutathione reductase. In: Bergmeyer HU, editor. Methods of Enzymatic Analysis. Verlag Chemie, Deerfield Beach; 1983:258-265.

38. Paglia DE, Valentine WN. Studies on the quantitative and qualitative characterization of erythrocyte glutathione peroxidase. J Lab Clin Med. 1967;70:158-169.

39. Bradford MM. A rapid and sensitive method for the quantitation of microgram quantities of protein utilizing the principle of protein-dye binding. Anal Biochem. 1976;72:248-254.

40. Mandal S, Singh RK, Dhar A, Ray SK. Optical and structural characteristics of $\mathrm{ZnO}$ thin films grown by rf magnetron sputtering. Mat Res Bull. 2008;43:244-250.
41. Patterson AL. The Scherrer formula for X-ray particle size determination. Phys Rev. 1939;56:978-982.

42. Wang M, Thanou M. Targeting nanoparticles to cancer. Pharmacol Res. 2010;62:90-99.

43. Li J, Guo D, Wang X, Wang H, Jiang H, Chen B. The photodynamic effect of different size $\mathrm{ZnO}$ nanoparticles on cancer cell proliferation in vitro. Nanoscale Res Lett. 2010;5:1063-1071.

44. Hackenberg S, Scherzed A, Kessler M, Froelich K, Ginzkey C, Koehler C, et al. Zinc oxide nanoparticles induce photocatalytic cell death in human head and neck squamous cell carcinoma cell lines in vitro. Int J Oncol. 2010;37:1583-1590.

45. Schrand AM, Braydich-Stollel LK, Schlager JJ, Dai L, Hussain SM. Can silver nanoparticles be useful as potential biological labels? Nanotechnology. 2008;19:235104.

46. Bai W, Zhang Z, Tian W, He X, Ma Y, Zhao Y, et al. Toxicity of zinc oxide nanoparticles to zebrafish embryo: a physicochemical study of toxicity mechanism. J Nanopart Res. 2009;12:1645-1654.

47. Ahamed M, Posgai R, Gorey TJ, Nielsen M, Hussain S, Rowe J. Silver nanoparticles induced heat shock protein 70 , oxidative stress and apoptosis in Drosophila melanogaster. Toxicol Appl Pharmacol. 2010;242:263-269.

48. Ahamed M, Siddiqui MA, Akhtar MJ, Ahmad I, Pant AB, Alhadlaq HA. Genotoxic potential of copper oxide nanoparticles in human lung epithelial cells. Biochem Biophys Res Commun. 2010;396:578-583.

49. Wu Y-N, Yang L-X, Shi X-Y, Li I-C, Biazik JM, Ratinac KR, et al. The selective growth inhibition of oral cancer by iron core-gold shell nanoparticles through mitochondria-mediated autophagy. Biomaterials. 2011;32:4565-4573.

50. Nair S, Sasidharan A, Rani VD, Menon D, Nair S, Manzoor K, et al. Role of size scale of $\mathrm{ZnO}$ nanoparticles and microparticles on toxicity toward bacteria and osteoblast cancer cells. J Mater Sci: Mater Med. 2009;20:S235-S241.

51. Zhu X, Wang J, Zhang X, Chang Y, Chen Y. The impact of ZnO nanoparticle aggregates on the embryonic development of zebrafish (Danio rerio). Nanotechnology. 2009;20:195103.

52. Gojova A, Guo B, Kota RS, Rutledge JC, Kennedy IM, Barakat AI. Induction of inflammation in vascular endothelial cells by metal oxide nanoparticles: effect of particle composition. Environ Health Perspect. 2007;115:403-409.

53. Moos PJ, Chung K, Woessner D, Honeggar M, Cutler NS, Veranth JM. $\mathrm{ZnO}$ particulate matter requires cell contact for toxicity in human colon cancer cells. Chem Res Toxicol. 2010;23:733-739.

54. Kilari S, Pullakhandam R, Nair KM. Zinc inhibits oxidative stressinduced iron signaling and apoptosis in Caco-2 cells. Free Radical Biol Med. 2010;48:961-968.

55. Gopinath P, Gogoi SK, Sanpui P, Paul A, Chattopadhyay A, Ghosh SS. Signaling gene cascade in silver nanoparticle induced apoptosis. Colloids Surf Bioint. 2010;77:240-245.

56. Compton MM. A biochemical hallmark of apoptosis: internucleosomal degradation of the genome. Cancer Metastasis Rev. 1992;11:105-119.

57. Sánchez-PérezY, Chirino YI, Osornio-Vargas AR, Morales-Bárcenas R, Gutiérrez-Ruíz C, Vázquez-López I, et al. DNA damage response of A549 cells treated with particulate matter $\left(\mathrm{PM}_{10}\right)$ of urban air pollutants Cancer Lett. 2009;278:192-200.

58. Ryter SW, Kim HP, Hoetzel A, Park JW, Nakahira K, Wang X, et al. Mechanisms of cell death in oxidative stress. Antioxid Redox Signal. 2007;9:49-89.

59. Akhtar MJ, Ahamed M, Kumar S, Siddiqui H, Patil G, Ashquin M, et al. Nanotoxicity of pure silica mediated through oxidant generation rather than glutathione depletion in human lung epithelial cells. Toxicology. 2010;276:95-102.

60. Ahamed M, AlSalhi MS, Siddiqui MKJ. Silver nanoparticle applications and human health. Clin Chim Acta. 2010;411:1841-1848.

61. Ahamed M. Toxic response of nickel nanoparticles in human lung epithelial A549 cells. Toxicol In Vitro. 2011;25:930-936. 
International Journal of Nanomedicine

Dovepress

\section{Publish your work in this journal}

The International Journal of Nanomedicine is an international, peerreviewed journal focusing on the application of nanotechnology in diagnostics, therapeutics, and drug delivery systems throughou the biomedical field. This journal is indexed on PubMed Central, MedLine, CAS, SciSearch ${ }^{\circledR}$, Current Contents ${ }^{\circledR} /$ Clinical Medicine,
Journal Citation Reports/Science Edition, EMBase, Scopus and the Elsevier Bibliographic databases. The manuscript management system is completely online and includes a very quick and fair peer-review system, which is all easy to use. Visit http://www.dovepress.com/ testimonials.php to read real quotes from published authors.

Submit your manuscript here: http://www.dovepress.com/international-journal-of-nanomedicine-journal 